\title{
ПОЗИЦИЯ КОНСТИТУЦИОННОГО СУДА РОССИЙСКОЙ ФЕДЕРАЦИИ В ЧАСТИ ВЗЫСКАНИЯ УБЫТКОВ, ПОНЕСЕННЫХ В РАМКАХ ДЕЛА О НЕСОСТОЯТЕЛЬНОСТИ «БАНКРОТСТВЕ»
}

\author{
(c) 2021 Казанкова Татьяна Николаевна \\ кандидат педагогических наук \\ Самарский государственный экономический университет, Россия, Самара
}

(C) 2021 Ремесленникова Анна Анатольевна

Начальник отдела обеспечения процедур банкротства

ИФНС России по Советскому району г. Самары, Россия

(C) 2021 Захаров Алексей Леонидович

кандидат юридических наук

Самарский государственный экономический университет, Россия, Самара

В статье исследуется вопрос о применении выводов Конституционного Суда, изложенных в Постановлении № 14-П, о наличии у налоговых органов права на обращение в суд с требованием о возмещении убытков, причинённых государству гражданами, вследствие не исполнения обязанности по подаче заявления в арбитражный суд о признании должника несостоятельным банкротом. Изложены некоторые рекомендательные предложения по недопущению увеличения расходов в процедурах банкротства должника.

Ключевые слова: несостоятельность(банкротство), возмещение убытков, расходы связанные с процедурой банкротства, арбитражный управляющий.

Вопрос о взыскании убытков, понесенных в результате дел о несостоятельности банкротстве не мог не найти своего отражения в разъяснении позиции Конституционного суда Российской Федерации.

Процедура банкротства является конечной мерой взыскания задолженности в бюджет Российской Федерации, целью которой является максимальное удовлетворение требований всех участников процесса.

Инициирование процедуры банкротства предполагает применение должной меры осмотрительности, а ее реализация с формальной целью недопустима и может привести к расходам средств федерального бюджета.

Заявитель в деле о банкротстве должника должен помнить о том, что в случае недостаточности имущества и активов должника, за счет которых могут быть покрыты расходы за процедуру банкротства, впоследствии будет оплачивать данные расходы.

Рациональным способом минимизации наступления неблагоприятных последствий на стадии возбуждения производства, является всесторонняя оценка ее целесообразности. Если организация-должник отвечает критериям недостаточности имущества и отсутствия в дальнейшем благоприятного эффекта от данной процедуры, уполномоченному органу необходимо принять меры, направленные на прекращение данной процедуры.

Банкротство не является единственным способом взыскания задолженности с должника. Если организация отвечает критериям недействующего юридического лица, прекращение деятельности данной организации возможно по решению самого налогового органа с последующим исключением данного общества из единого государственного реестра юридических лиц.

Однако такой подход привел бы к автоматическому снятию ответственности с лиц, учредивших и контролирующих деятельность организаций, а безнаказанность данного метода к увеличению фирм однодневок, целью которых является не фактическое ведение деятельности организации, а сокрытие доходов и уход от ответственности.

В этой связи, необходима разработка определенной концепции по оценке мероприятий, за счет которых будет достигнут максимальный 
эффект от данной процедуры. К данным мероприятиям относятся не только поступления от реализации ликвидных активов ответчика, но и проведение анализа оснований для оспаривания сделок должника, экономическая целесообразность привлечения конечных бенефициаров к субсидиарной ответственности, как в рамках, так и вне рамок процедуры банкротства. Необходимо также оценить преднамеренность (фиктивность) предпосылок приведших к банкротству организации с целью последующего взыскания убытков с ответчиков.

Данный подход предусматривает инициирование производства в отношении результативных процедур и максимизацию формирования конкурсной массы, что отвечает задачам, поставленным перед уполномоченным органом по:

- недопущению финансирования за счёт бюджетных средств;

- недопущению непринятия мер по возложению обязанности по погашению задолженности, подлежащей списанию, на контролирующих должника лиц при их наличии.

Законодательство о несостоятельности содержит в себе механизмы, позволяющие избежать необоснованных расходов на ее проведение не только на стадии возбуждения, но и в самих процедурах.

По мнению Конституционного Суда, указанную проверку, в целях недопущения образования и/или увеличения расходов, непогашенных за счёт конкурсной массы, должны проводить заявитель, арбитражный суд, арбитражный управляющий.

При этом Конституционный Суд обратил внимание, что к возникновению (увеличению) таких непогашенных расходов могут привести ненадлежащие действия (бездействие) ряда лиц, а значит необходимо определить весь круг лиц, неправомерные действия которых могут влиять как на объём имущества должника, за счёт которого будут погашаться расходы по делу о банкротстве, так и на размер этих расходов [1]. К указанным лицам, Конституционный Суд отнёс:

- руководителя должника;

- лиц, имеющих право созыва общего собрания акционеров (участников);

- акционеров (участников);

- иных контролирующих должника лиц;

- арбитражного управляющего;

- заявителя по делу о банкротстве.
Таким образом, территориальным налоговым органам на постоянной основе необходимо проводить анализ на предмет возможности возникновения (увеличения) непогашенных за счёт конкурсной массы судебных расходов, оплаты вознаграждения арбитражному управляющему и привлечённым специалистам. В отношении привлекаемых специалистов, необходимо дать оценку целесообразности их привлечения с учетом размера оплаты и оказываемых ими услуг.

Учитывая, что на каждой стадии банкротства есть ответственный субъект осуществляющий проверку возможности погашения расходов по делу о банкротстве, уполномоченному органу необходимо инициировать чёткое выражение указанным субъектом своей позиции относительно достаточности активов должника для дальнейшей процедуры банкротства [3].

Полнота сведений, отраженных в отчете арбитражного управляющего позволяет на любой стадии сделать вывод о целесообразности продления производства, исходя из предполагаемого размера экономической выгоды. А в случае наступления неблагоприятных последствий, своевременно принять меры по ее прекращению, заняв активную процессуальную позицию при рассмотрении арбитражным судом отчёта конкурсного управляющего, добиваясь представления арбитражному суду всех необходимых сведений, на основе которых суд может прийти к обоснованному выводу о возможности продления срока конкурсного производства.

Результатом указанной работы должна стать осведомлённость всех лиц, принимающих решение о продолжении конкурсного производства на основании сведений о наличии имущества, включённого в конкурсную массу, его стоимостной оценке и достаточности (или недостаточности) для погашения как уже произведённых, так и будущих расходов по делу о банкротстве.

Несмотря на все мероприятия, направленные на недопущение расходов в процедуре банкротства, заявитель по делу о банкротстве, обратившийся в суд с указанным заявлением и погасивший вследствие этого расходы, связанные с процедурой банкротства, несет убытки. Заявитель по делу о банкротстве понесший расходы в рамках процедуры банкротства и погасивший их в следствии исполнения обязанности, возложенной Законом о несостоятельности(банкротстве) на контролирующих должника лиц, фактически понес убытки. 
Возмещение убытков лицу, чье право было нарушено регламентируется Гражданским кодексом Российской Федерации и предусматривает ответственность за вред, причиненный не только личности, но и имуществу этого лица.

Способом возмещения убытков является инициация судебного процесса судом общей юрисдикции с исковыми требованиями о взыскании их с ответчика [4].

Выступая истцом в данном деле, налоговые органы прежде всего являются публично-правовым образованием, лишившимся собственности (в конституционном смысле этого слова) вследствие действия (бездействия) гражданина, а конституционная позиция о принципе равенства всех перед законом дает возможность воспользоваться способами судебной защиты гражданских прав, включая право на взыскание убытков.

При привлечении к деликтной ответственности необходимо доказать весь состав гражданского правонарушения, который, предполагает наступление вреда именно вследствие виновных противоправных действий его причинителя.

Оценивая весь состав правонарушения судами учитываются критерии справедливости и соразмерности заявленных требований, а обращение лишь с точки зрения неисполнение возложенных обязанностей на руководителя должника не отвечает требованиям закона, его действия не могут быть квалифицированы как противоправное поведение, направленное на причинение вреда.

В случае устанавливая ответчика необходимо сопоставить период деятельности каждого из руководителей и руководствоваться не принципом привлечения последнего к ответственности, а установления реального ответчика, нарушившего данную обязанность. Для этого необходимо четко установить момент наступления признаков банкротства путем проведения анализа финансово - хозяйственной деятельности организации исходя из бухгалтерской отчетности. Кроме того, необходимо дать анализ действиям руководителя организации по выводу ее из состояния нестабильности.

Противоправность поведения характеризуется действиями руководителя, как в самой процедуре, так и в ее преддверии. В случае установления факта отказа от передачи арбитражному управляющему документации организации, печатей, сокрытия имущества, отчуждение активов, как в самой процедуре, так и до ее возбуждения явно говорят о его противоправном поведении, направленном на причинение вреда иным участникам процесса.

Всесторонняя оценка всех необходимых составляющих гражданско - правового процесса может свидетельствовать как о наличии вицы ответчика, так и о его невиновности. В связи с чем, необходима всесторонняя оценка доказательной базы включающей в себя анализ периода возникновения обязанности по наступлению обязанности обращения в арбитражный суд с заявлением по инициированию производства о несостоятельности, установлению не номинального ответчика в данном деле, его вину и действия, которые привели к данным последствиям.

Отсутствие единообразия применения норм права в данном вопросе нашло свое отражение в Постановлении Конституционного суда Российской Федерации № 14-П от 05.03.2019 г., в котором был рассмотрен вопрос о его конституционности.

С одной стороны выступает гражданин, который в силу своих обязательств несет ответственность перед истцом личным имуществом, с другой стороны выступает государственный орган, который уже понес убытки средствами федерального бюджета.[2] Следствие недобросовестного поведения одного из них, приводит к нарушению прав другого.

Подводя итоги написания данной статьи, можно сделать вывод о том, что только соблюдение четкого баланса между правами и свободой гражданина с одной стороны, и механизмами, направленными на недопущение причинения убытков бюджету Российской Федерации, свидетельствует об эффективной работе органов государственной власти.

Инициируя процедуру банкротства в отношении юридического лица, необходимо не только исходить из ее экономической целесообразности, но и иметь четкое представление о том, какие мероприятия в рамках процедуры банкротства должника, позволят достичь максимального эффекта в более короткие сроки. Институт банкротства на сегодняшний день одна из самых сложных процедур, которая связана с выполнением многочисленных правовых действий. Существует множество нормативных актов, которые регулируют весь процесс несостоятельности (банкротства). 
Процесс формирования и реформирования правового института несостоятельности (банкротства) продолжается в настоящее время и является сравнительно новым для отечественной правовой системы, в связи с чем, проблематика данного вопроса, является актуальной и значимой в рамках формирования законодательной базы.

\section{Библиографический список}

1. «Конституция Российской Федерации». Часть первая, третья, четвертая: принята всенародным голосованием 12.12.1993 (с изменениями, одобренными в ходе общероссийского голосования 01.07.2020). База данных «Консультант Плюс». Retrieved from: http://www.consultant.ru/document/cons_doc_LAW_28399/ (дата обращения: 05.10.2020)/.

2. Постановление Конституционного Суда РФ от 05.03.2019 N 14-П «По делу о проверке конституционности статьи 15, пункта 1 статьи 200 и статьи 1064 Гражданского кодекса Российской Федерации, подпункта 14 пункта 1 статьи 31 Налогового кодекса Российской Федерации, абзаца второго пункта 1 статьи 9, пункта 1 статьи 10 и пункта 3 статьи 59 Федерального закона «О несостоятельности (банкротстве)» в связи с жалобой гражданина В.А. Нужина». База данных «Консультант Плюс». Retrieved from: https://legalacts.ru/doc/ postanovlenie-konstitutsionnogo-suda-rf-ot-05032019-n-14-p-ро/(дата обращения: 05.10.2020)/.

3. Федеральный закон «О несостоятельности (банкротстве)» от 26.10.2002 N 127-Ф3: принят Гос.Думой 27 сентября 2002 г. одобр. Советом Федерации 16 октября 2002 г. База данных «Консультант Плюс». Retrieved from: http://www.consultant.ru/document/cons_doc_LAW_39331/ (дата обращения: 05.10.2020)/.

4. Гражданский Кодекс Российской Федерации. Часть вторая: Федер. закон от 18 декабря 2006 г. № 230-ФЗ: принят Гос. Думой 24 ноября 2006 г: одобр. Советом Федерации 8 декабря 2006 г. (в ред. Федер. закона от 23 мая 2018 г. № 116-Ф3) Retrieved from: http://www.consultant.ru/document/cons_doc_LAW_9027/ (дата обращения: 05.10.2020)/. 